\title{
Effect of Different Agro-wastes Substrates on the Growth and Productivity of the Oyster Mushroom in Upper Egypt
}

\author{
Rafat Khalaphallah ${ }^{1}$, Tharwat EL-Ameen ${ }^{2}$, \\ Reham A. Abd EL-Rahmen ${ }^{3 *}$ and Eman S. Farrag ${ }^{3}$ \\ ${ }^{1}$ Department of Agricultural Botany (Microbiology), Faculty of Agriculture, \\ South Valley University, Qena, Egypt \\ ${ }^{2}$ Department of Agricultural Botany (Genetics), Faculty of Agriculture, South Valley \\ University, Qena, Egypt; ${ }^{3}$ Department of Clinical Laboratory Science (Microbiology), Faculty \\ of Applied Medical Science, University of Hafr Al Batin, Hafr Al Batin, \\ Kingdom of Saudi Arabia \\ *Corresponding author
}

\section{A B S T R A C T}

The Oyster mushroom (Pleurotus cystidiosus) was cultivated on different agrowastes as substrates such as; sugarcane bagasse $(\mathrm{ScB})$, rice straw (RS), and wheat straw (WS), whereas the fourth formula composed of combination of these three substrates in a proportion of 1: 1. The ScB, RS and WS agro-wastes substrates were selected as the most favorable lignocellulosic sources. P. cystidiosus can

\section{Keywords}

Oyster mushroom, Agro-wastes, Environmental conditions, Bio efficiency

\section{Article Info}

\section{Accepted:}

04 March 2020

Available Online:

10 April 2020 efficiently degrade the agro-wastes and grow at wide range of temperatures. The effects of growing the Oyster mushroom on different lignocllulosic agro-wastes as substrates were tested through evaluating the levels of various parameters in the growing mycelium including: moisture contents, yield, total carbohydrates, crude fat, crude protein, crude fiber, ash, and minerals contents. The WS showed the highest yield (97\% Bio efficiency), maximum crude protein (23\%), and phosphorus content of $(890 \mathrm{mg} / 100 \mathrm{~g}$ of dry mushroom). The $\mathrm{ScB}$ recorded minimum moisture $(88 \%)$ and crude fiber content $(9 \%)$. However, the maximum moisture $(91 \%)$ and highest fruiting bodies size $(10 \mathrm{~cm})$ are recorded on RS cultivation. The combination of substrates formula $\mathrm{ScB}+\mathrm{WS}+\mathrm{RS}$ expressed the highest carbohydrate content (58\%), ash (7.1\%), phosphorus $(585 \mathrm{mg} / 100 \mathrm{~g}$ of dry mushroom), and calcium (320 mg/ 100g of dry mushroom) content. Finally, we concluded that the P. cystidiosus of Upper Egypt can grow in a wide range of temperatures and substrates mainly on WS, then Rs, and ScB. The aim of the current work was to study the influences of the different agro-wastes substrates and some nutritional conditions on the mycelial growth of $P$. cystidiosus, during winter season in the Upper Egypt. 


\section{Introduction}

Recently, the problem of wastes accumulation and the challenges of food production are the most important problems facing the world, especially with the interest of growing and environmental awareness. There is a great interest towards biodegradation of the agricultural wastes in the developing countries such as; rice straw, wheat straw, and sugar cane bagasse). In addition, all the cellulosic residues of the fields are currently used along with the other food wastes to increase the development and production of mushrooms. The Oyster mushroom ( $P$. cystidiosus) is the second widely cultivated mushroom worldwide following the Agaricus bisporus (Kues and Liu, 2000). P. cystidiosus is popular and widely cultivated mostly in the Upper Egypt. The conditions of the Upper Egypt region mainly high temperature are suitable for $P$. cystidiosus growth, in addition to low cost of production technology and the high biological efficiency (BE) (Mane et al., 2007). P. cystidiosus belongs to the family Tricholomataceae, and composed of about fourty species that are cultivated in different parts of Egypt. It can grow well on different types of lignocellulosic substrates and at different temperature conditions. Chang et al., (1989) reported that $P$. cystidiosus is ideally suited for cultivation throughout the year in various regions of the tropical countries, and is ranked next to A. bisporus, throughout the world in terms of yield and production. Jandiak et al., (1995) reported that $P$. cystidiosus is an efficient lignin degrader which can grow on a wide variety of agricultural wastes, and at a wide range of temperatures. This Oyster mushroom has high economical and medicinal values, due to its chemical composition andlor nutrition. Li et al., (2007) added that several species of Oyster mushroom are very important in the field of medicine acting as strong antioxidants. P. cystidiosus possesses antitumor activity, and has hypoglycaemic accents in experimentally induced diabetics (Chorvathova et al., 1993). Oyster mushroom is able to colonize and degrade a large variety of lingocellulosic materials and other wastes, which are produced in agricultural, forest and food processing industries (Gracha et al., 1993). Previously, Tesfaw et al., (2015) pointed that it contains $91 \%$ of water and $10 \%$ of dry matter; in addition, its nutritional value can be compared with milk, eggs and meat. Kurtzman, (1967); Hayes Haddad, (1976); Szabova et al., (2013) added that Oyster mushroom is rich in organic components including: vitamins (thiamine, riboflavin, folic and niacin), proteins and minerals, and is considered to be intermediate between that of vegetables and animals. Moreover, it contains all the 9 essential amino acids. This type of mushroom contains high of potassium to sodium ratio, which makes it an ideal food for patients suffering from hypertension and heart diseases (Dehariya et al., 2013). According to Bano et al., (1993); Cohen et al., (2002), cultivation of Oyster mushroom offers the most feasible and economic method for agrolignocellulosic wastes biodegradation. These biodegrading technologies can also limit air associated with burning agriculture wastes, as well as to decrease environmental pollution due to these unutilized agricultural wastes. The current study aimed to evaluate the optimal nutritional conditions for mycelial growth and production of Oyster mushroom under the conditions of Upper Egypt.

\section{Materials and Methods}

\section{Substrate preparation and inoculation}

Two agro wastes substrates including (ScB) and (WS) were obtained from Qena governorate farms, Egypt. The RS and WS were dried and then ground into $0.5-2 \mathrm{~cm}$ length pellets, and then soaked separately in water over $2 \mathrm{~h}$. In order to determine the 
suitable substrates for cultivation of mushroom, three substrates including RS, WS, ScB were used, while the fourth substrate formula was composed of their total combination at a proportion of $1: 1$, following the method of Bano et al., (1982) with slight modifications. Three replicates were used for each substrate formula, they were cooled to room temperature, and then the bags were inoculated with the mushroom spawn.

\section{Mushroom spawn cultivation}

The polyethylene bags of the size $30 \times 50 \mathrm{~cm}$ were filled with sterilized agro-substrates, and the multilayered techniques were adapted for mushroom spawns cultivation (Baysal et al., 2003). About $5 \mathrm{~kg}$ of dry substrate was filled in each bag. After inoculation with the spawn, the bags were kept in the greenhouse where the temperature and humidity were maintained at $25^{\circ} \mathrm{C}$ and $80-90 \%$; respectively, with sufficient light for $20 \mathrm{~d}$. The polyethylene bags were tear-off after the incubation period, and the spawn runs was completed within $18 \mathrm{~d}$. The beds were maintained till the harvest of the third flush, which was completed in $35 \mathrm{~d}$ after spawning.

\section{Biological efficiency and moisture content}

The total weights of all the fruiting bodies harvested from the three picking were measured as the total yield of mushroom. The biological efficiency (B.E.) (yield of mushroom per $\mathrm{kg}$ substrate on dry weight basis) was calculated by the following formula of Chang et al., (1981):

B.E. $(\%)=($ Fresh weight of mushroom/ Dry weight of substrate) $\times 100$

According to Syed et al., (2009), the moisture content (M.C) of the mushroom was also expressed in percentage, and calculated by the following formula:
M.C $(\%)=($ Weight of fresh sample - weight of dry sample/ Weight of fresh sample) $\times 100$

\section{Nutritional analysis}

The Protein content, fat, ash and total carbohydrates were determined with the procedure recommended by Wankhede et al., (1976); AOAC. (1995). The crude fibers and calcium were determined according to Ranganna, (1986). Whereas the mineral contents $(\mathrm{K}, \mathrm{Mg}$ and $\mathrm{Zn}$ ) were analyzed by the flam and spectrophotometer in reference to Ezeibekwe et al., (2009), after extraction of the elements in $0.1 \mathrm{~N} \mathrm{HCl}$ acidic solutions.

\section{Mushroom incubation and harvest}

According to Tesfaw et al., (2015), the inoculated substrates were kept in an incubator at $28^{\circ} \mathrm{C}$ and $70-80 \%$ relative humidity $(\mathrm{RH})$ under dark conditions. After the substrates surface was entirely covered with the mushroom mycelium, they were moved to an incubation room having temperature of $24^{\circ} \mathrm{C}$, and kept at $\mathrm{RH}$ of about $90 \%$ or above.

Finally, the stipe length (mm), the cap diameter $(\mathrm{cm})$, and the Fresh weight $(\mathrm{g})$ were measured at the first, second and the third flush, and then the means were also determined at the end of harvest. These accumulated data were used to calculate total yield and the biological efficacy (B.E.).

\section{Statistical analysis}

The experiments were arranged in a randomized complete block design with three replicates.

One-way analysis of variance (ANOVA) was conducted with Duncan's multiple range tests to compare the mean significant differences $(\mathrm{p}<0.05)$ among the treatments 


\section{Results and Discussion}

There are differences recorded concerning the cap diameter of $P$. cystidiosus grown on the different substrates formula (Table 1). The cap diameter is the highest $(10 \mathrm{~cm})$ on RS and substrate formula Ws+ Rs, conversely the lowest cap diameter $(8 \mathrm{~cm})$ is recorded on using $\mathrm{ScB}$. The WS is recorded to be the superior over than other agro-wastes in mushroom production parameters in agreement with Philippoussis, (2003). Moreover, mixing of the agro-wastes at different ratios enhanced the productivity. Figure 1 demonstrates that the lengths of the Oyster mushrooms stipes are changed with the use of the different agro-waste substrates. The stipe length ranged from $32-43 \mathrm{~mm}$, while the lowest stipe $(32 \mathrm{~mm})$ is recorded on using the substrate formula RS+ ScB (Table 1). The values of the stipe lengths of the Oyster mushroom grown on the different substrate formulas are almost the same or lower than those of other experimental substrates ( $\mathrm{ScB}, \mathrm{RS}$ and WS agro-wastes), while the thickness values are the same or higher, according to Dehariya et al., (2013).

The data in Table 2 show that the fresh weight of each picking of the Oyster mushrooms on the lignocllulosic agro-wastes WS- Rs- ScB substrates is lower than that of the other substrate formulas. The total yields of the Oyster mushroom on using the formula of Ws+ RS+ ScB are of good remarkable quantities. The WS presents the maximum number of fruiting bodies and fresh weights, followed by $\mathrm{ScB}$, whereas the lowest number is recorded by RS. These variations are probably attributed to the difference of the bulk density and constituents of the agrowaste substrates. The yields of mushroom are correlated positively with the cellulosic content, but negatively with the lignin and phenoloic contents, in agreement with the findings of Sivaprakasm (1986).
The maximum yield of $P$. cystidiosus is obtained on using WS (970 g/ 5kg straw) with B.E. of $97 \%$, followed by the yield on WS+ $\mathrm{ScB}(850 \mathrm{~g} / 5 \mathrm{~kg}$ straw) with B.E. of $85 \%$, while the least yield is recorded on using WS+ RS agro-waste (770 g/ kg straw).

The maximum moisture content is recorded on using the $\mathrm{ScB}$ (91\%), followed by WS (90\%). However, there is a slight variation with the other substrates indicating that the moisture content is independent of the substrate. The performance of the three substrates is also evident by their elevated B.E. values on using the WS followed by RS (Table 2). The recorded time required for harvest of the fruiting bodies in WS is always preceded by the RS or RS combination. Cultivation of the $P$. cystidiosus on similar by-products has manifested variable levels of B.E. According to Mane et al., (2007), these variations are mainly related to the spawn rate, fungal species, and to the supplements added to the substrates. Sharma et al., (2013) pointed out that some of the recorded B.E. of the Oyster mushroom on the common substrates such as RS is $85.5 \%$, but on the leguminous plants the B.E. is $103.8 \%$. The total yield of the Oyster mushroom currently recorded is similar the earlier studies of Raina et al., (2009); Patil, (2012).

The protein, fat, carbohydrates, crude fiber and ash contents of the mature fruiting bodies of $P$. cystidiosus cultivated on different lingocellulosic substrates alone or in combination are shown in Figure 2. The mushroom fruiting bodies produced on WS expressed the highest protein content of $23 \%$ on a dry weight basis, followed by WS+ RS (22\%). The highest fat content of the Oyster mushroom is recorded on using the WS+ RS combination (3.9\%), followed by $\mathrm{ScB}(2.5 \%)$. The current protein and fat contents are similar to the earlier studies of Patil and Dakorem, (2007); Patil et al., (2008). The 
maximum carbohydrate content of the mushroom is $67 \%$ in fruiting bodies cultivated on $\mathrm{ScB}$, whereas the least is $51 \%$ on cultivation on the $\mathrm{WS}+\mathrm{ScB}$, which is consistent with the results of Patil et al., (2008). The highest records of crude fiber is observed on $\mathrm{ScB}$ (702\%), followed by WS formula $(6.9 \%)$. The other agro-wastes alone or in combination also yielded appreciable levels of crude fiber. These results are in agreement with the earlier findings of
Khyadagi et al., (1998); Singh et al., (2003); Bhattacharjya et al., (2014). The protein content usually ranges between $20-30 \%$ on a dry weight basis. Patil et al., (2008) revealed that the substrates rich in usable nitrogen may be a considerable factor in enhancing the mushroom yield and quality, in addition to the mushroom spices with respect to the bioconversion and bioaccumulation efficiencies.

Table.1 Represent the data of caps diameter, length of stipes and the fresh weights after 3 flushes at the winter season

\begin{tabular}{|c|c|c|c|}
\hline $\begin{array}{c}\text { Agro- } \\
\text { waste } \\
\text { substrates }\end{array}$ & $\begin{array}{c}\text { Cap } \\
\text { diameter } \\
(\mathbf{c m})\end{array}$ & $\begin{array}{c}\text { Fresh weight (g)/ bag } \\
\text { dry straw }\end{array}$ & $\begin{array}{c}\text { Length } \\
\text { of the } \\
\text { stipe } \\
(\mathbf{m m})\end{array}$ \\
\hline WS & 9.5 & 410 & 35 \\
\hline RS & 10 & 355 & 33 \\
\hline ScB & 8 & 380 & 34 \\
\hline $\begin{array}{c}\text { ScB+ } \\
\text { WS+ RS }\end{array}$ & 10 & 390 & 36 \\
\hline WS+ RS & 10 & 370 & 43 \\
\hline RS+ ScB & 9 & 395 & 32 \\
\hline ScB+ WS & 9 & 400 & 41 \\
\hline
\end{tabular}

Table.2 Effect of the agro-waste substrates on the total yield, B.E. and moisture content of the Oyster mushroom

\begin{tabular}{|l|c|c|c|c|c|c|}
\hline $\begin{array}{c}\text { Agro-waste } \\
\text { Substrates }\end{array}$ & 1 picking & 2 picking & 3 Picking & Total yield (g)/ & $\begin{array}{c}\text { Bio efficiency } \\
\text { (B.E) }\end{array}$ & Moisture \% \\
\hline (WS) & 440 & 230 & 200 & 970 & 97 & 90 \\
\hline (RS) & 355 & 275 & 150 & 780 & 78 & 88 \\
\hline (ScB) & 380 & 260 & 170 & 810 & 81 & 91 \\
\hline WS+ RS+ ScB & 390 & 240 & 160 & 790 & 79 & 89 \\
\hline RS+ ScB & 395 & 230 & 155 & 780 & 78 & 89 \\
\hline ScB+ WS & 400 & 310 & 140 & 850 & 85 & 88 \\
\hline WS+ Rs & 370 & 240 & 160 & 770 & 77 & 89 \\
\hline
\end{tabular}


Fig.1 The oyster mushroom growth bag

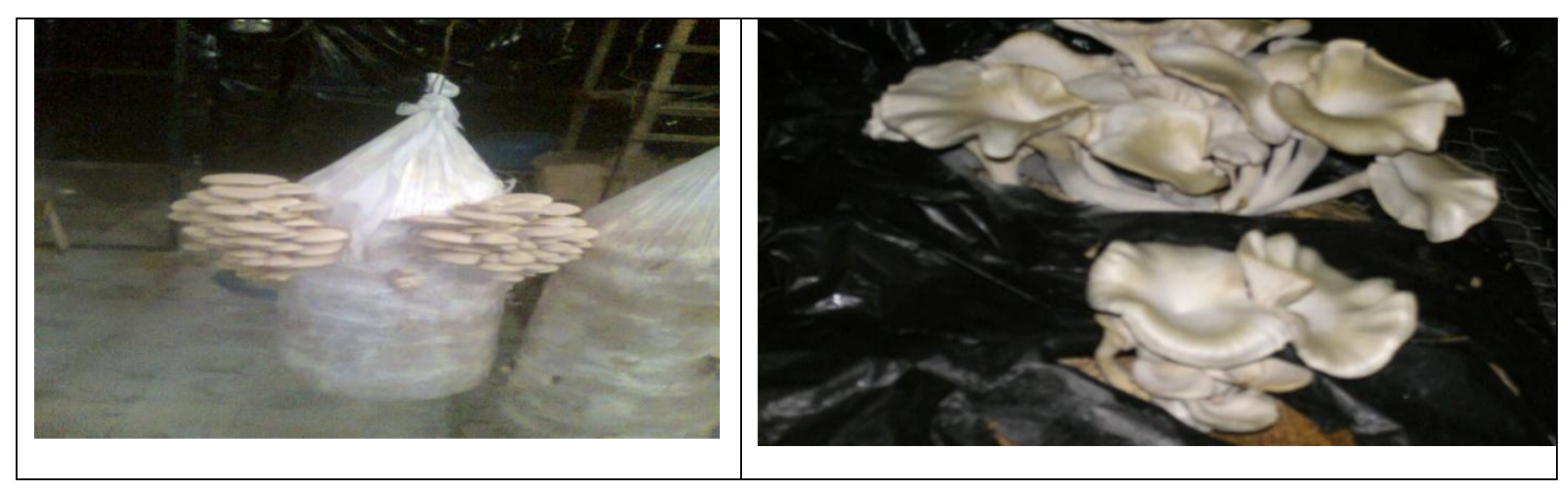

Fig.2 Effects of the different agro-wastes on the protein, carbohydrates, fat, fiber and ash contents of the Oyster mushroom

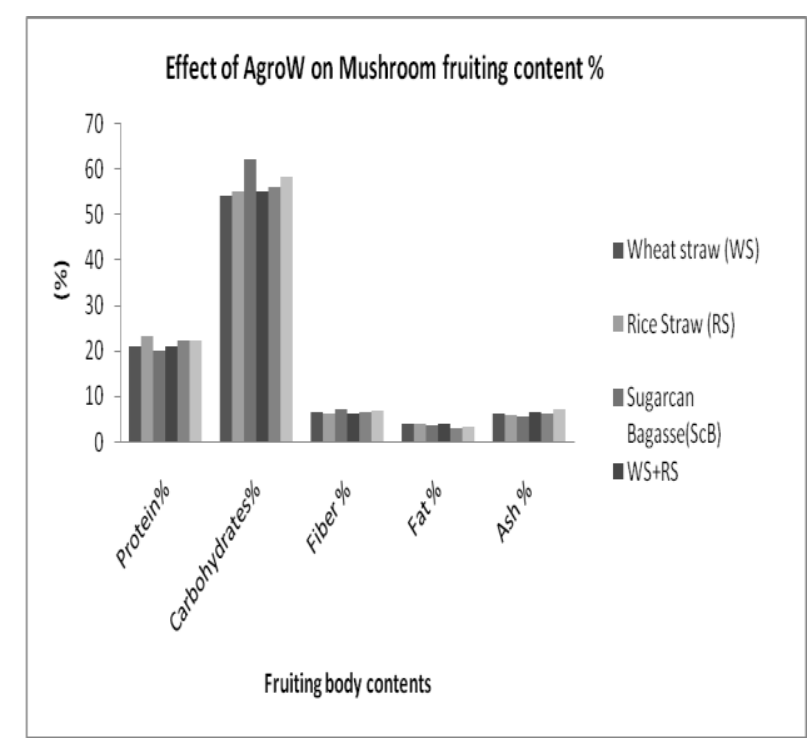

Fig.3 Effects of the agro-wastes substrates on the N, P, K Mg, Zn and Ca contents (mg/ 100g) of the Oyster mushroom

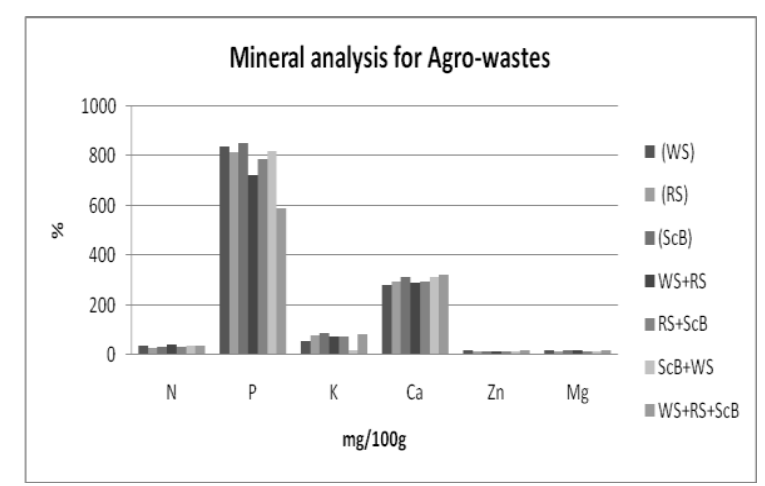


The maximum ash content of Oyster mushroom is found on using the combination of Ws+ Rs+ ScB (7.5\%), followed by mushroom grown on WS+ RS $(6.5 \%)$, similar results were reported by Patil et al., (2001). In a previous study, Quimio, (1987) reported that cellulose rich organic substances are good substrates for the cultivation of mushroom. Agro-waste substrates with high lignin and phenolic contents decrease the activity of cellulose, however less lignin content would enhance the enzyme activity and thus ensure higher yield of the mushroom (Sivaprakasam, 1980). The highest calcium (Ca) content is recorded when Oyster is grown on substrate formula of Ws + Rs (310 $\mathrm{mg} / 100 \mathrm{~g}$ ), followed by $\mathrm{ScB}+\mathrm{WS}$ (280mg/ $100 \mathrm{~g}$ ), as clear in Figure 3. The phosphorus (p) content is maximum on using the $\mathrm{ScB}$ $(850 \mathrm{mg} / 100 \mathrm{~g}$ ), whereas the lowest content is observed in the formula of RS+ WS $(722 \mathrm{mg} /$ $100 \mathrm{~g}$ ), similar amount of $\mathrm{P}$ was also recorded by Caglarirmak (2007). The highest contents of Zink ( $\mathrm{Zn})$ and Magnesium $(\mathrm{Mg})$ in the mycelium of Oyster mushroom is achieved on WS (18mg/ 100g) substrate. The lowest potassium $(\mathrm{K})$ value is observed from the formula of WS+ RS, and is significantly lower than the other substrates formula. In the case of nitrogen $(\mathrm{N})$, the maximum content is achieved on using the substrate formula WS+ RS (39 mg/ 100g). These current results for the $\mathrm{K}, \mathrm{P}$ and $\mathrm{Ca}$ contents are in consistent with the previous studies of Ahmed et al., (2009); Patil et al., (2010); Patil et al., (2012),

According to the data of all agro-wastes estimated in this study, it can be concluded that $P$. cystidiosus in Upper Egypt can grow in a wide range of temperatures, and on several substrates. The best growth is recorded on WS then RS, and then on ScB. Accordingly, growing the Oyster mushroom on $\mathrm{WS}$ or $\mathrm{ScB}$ is less expensive, due to the availability of these agro-wastes in the surrounding environment. The use of the agro-wastes such as; ScB, RS and WS for Oyster mushroom cultivation is a new way of handling the plantations wastes.

\section{Acknowledgement}

We acknowledge the sponsors of South Valley University, Egypt, who helped the researcher in funding this research. We are also grateful to the Vice President of South Valley University, sector of Graduate Studies and Research. Finally, we are grateful to all staff members and technicians of the Agriculture Plant Botany Department.

\section{References}

Ahmed, S.A., Kadam, J.A, Mane, V.P., Patil S.S., Baig, M.M., 2009. Biological efficiency and nutritional contents of Pleurotus florida (Mont.) Singer cultivated on different agro-wastes. Natural Science 7, 44-48.

Association of Official Analytical Chemists. Official methods of analysis of AOAC International.16th ed. Washington, DC: Association of Official Analytical Chemists; 1995.

Bano Z, Rajarathnam S. Studies on cultivation of Pleurotus sajor-caju . Mushroom Journal. 1982; 115: 243245.

Baysal E, Peker H, Yalinkiliç MK, Temiz A. Cultivation of oyster mushroom on waste paper with some added supplementary material Bioresourc Technology. 2003; 89: 95-97.

Bhattacharjya DK, Paul RK, Miah MN, Ahmed KU. Effect of different saw dust substrates on the growth and yield of oyster mushroom (Pleurotus ostreatus) Journal of Agricultural and Veterinary Science 2014; 7: 38-46.

Caglarirmak N. 2007. The nutrients of exotic mushrooms (Lentinula edodes and 
Pleurotus species) and an estimated approach to the volatile compounds. Journal of Food Chemistry, 105: 11881194.

Cavins, T.J., Whipker, B.E., Fonteno, W.C., Harden B., McCall, I., Gibson, J.L., 2000.Monitoring and managing $\mathrm{pH}$ and EC using the Pour Thru extraction method. Horticulture Information Leaflet 590. Raleigh (NC): North Carolina State University

Chang, S.T., 2007.Mushroom cultivation using the "ZERI" principle: potential for application in Brazil. Micologia Aplicada International. 19, 33-34.

Chang, S.T., Miles, P.G. Edible mushroom and their cultivation.Boca Raton (FL): CRC Press; 1989.

Cheng, Z., Wu, Q., Huang, J.B., Hu, C.G., Wang, Z.L., 2013. Effects of carbon sources, nitrogen sources and minerals on mycelial growth of Cryphonectria parasitica. African Journal of Agricultural Research 8, 4390-4395.

Chorváthová, V., Bobek, P., Ginter, E., Klavanová J., 1993. Effect of the oyster fungus on glycemia and cholesterolemia in rats with insulin-dependent diabetes. Journal of Physiological Research. 42,175-179.

Dehariya, p., vyas D., 2013. effect of different agro-waste substrate and their combination on the yield and biological efficiency of Pleurotus sajor-caju. Journal of pharmacy and biological science. 8, 3, 60-64.

Dehariya, P., Vyas, D., Kashaw, S.K., 2013. Mushroom nutraceuticals on different substrates. International Journal of Pharmacy and Pharmaceutical Sciences. 5, 88-90.

Ezeibekwe, I.O., Ogbonnaya, C.I., Unamba, C.I., Osuala, O.M., 2009. Proximate analysis and mineral composition of edible mushrooms in parts of South Eastern Nigeria. Report and Opinion,
2009. 1: 32-36.

Garcha, H., Khanna, P., Soni, G., 1993. Nutritional importance of mushrooms. In: Chang S.T., Buswell J.A., Chiu S.W., editors. Mushroom biology and mushroom products. Hong Kong: Chinese University Press. Pp. 227-236.

Jandaik, C.L., Goyal, S.P., 1995. Farm and farming of oyster mushroom (Pleurotus sp.) In: Singh RP, Chaube HS, editors. Mushroom production technology. Tehri Garhwal: Govind Ballabh Pant University of Agriculture and Technology. Pp. 72-78.

Khydagi, K.S.; Sharda, G.S. and Meera Rao. Proximate composition of Oyster mushroom. Karnataka Journal. Agriculture Science. 1998; 11 (2): 548 549

Kües, U., Liu, Y., 2000. Fruiting body production in Basidiomycetes. Applied Microbiology and Biotechnology. 54, 141-152.

Li, L., Ng, T.B., Song, M., Yuan, F., Liu, Z.K., Wang, C.L., Jiang, Y., Fu, M., Liu, F.A., 2007. polysaccharide-peptide complex from abalone mushroom (Pleurotus abalonus) fruiting bodies increases activities and gene expression of antioxidant enzymes and reduces lipid peroxidation in senescenceaccelerated mice. Applied Microbiology and Biotechnology 75, 863-869.

Mane, V.P., Patil, S.S., Syed, A.A., Baig, M.M., 2007. Bioconversion of low quality lignocellulosic agricultural waste into edible protein by Pleurotussajor-caju (Fr.) Singer. Journal of Zhejiang University. 8, 745751.

Patil, S.S., 2012. Cultivation of Pleurotus ajor-caju on different agro wastes. Science research reporter. 2(3), 225228.

Patil, S.S., Ahmed, S.A., Telang, S.M., Baig, M.M., 2010. The nutritional value of 
Pleurotus ostreatus (Jacq.:Fr) Kumm cultivated lignocellulosic agro wastes. Innovative Romanian food biotechnology. 7, 66-76

Philippoussis, A.N., Diamantopou lou, P.A, Zervakis, G.I., 2003. Correlation of the propertie of several lignocellolosic substrates to the crop performance of shitake mushroom Lentinula edodes. World Journal of Microbiology and Biotechnology. 19, 551-557.

Purkayastha, R.P., Nayak D., 1981. Analysis of protein patterns of an edible mushroom by gel-electrophoresis and its amino acid composition. Journal of Food Science and Technology. 18, 8991.

Quimio, T.H., 1978. Introducing: Pleurotus flabellatus for your dinner table. Mushroom Journal 69, 282-283.

Raina, P.K., Savita, V., Anil G., Sharma, R.K., 2009. Evaluation of different substrates for the yield and yield related parameters in blue oyster mushroom. Mushroom Research 18(1), 11-16.

Ranganna, S. 1986. Handbook of Analysis and Quality Control for Fruit and Vegetable Products. Tata McGraw Hill Publishing Co. Ltd., New Delhi,; Pp. 190-210.

Sánchez, C., 2010. Cultivation of Pleurotus ostreatus and other edible mushrooms. Journal of Applied Microbiology and Biotechnology 85, 1321-1337

Sharma, S., Yadav, R.K., Pokhrel, C.P., 2013. Growth and yield of oyster mushroom
(Pleurotus ostreatus) on different substrates. Biology of Reproduction Journal. 2, 3-8

Sivaprakasam K. Studies on oyster mushroom (Pleurotus sajorcaju) Fr. [dissertation] Coimbatore: Tamil Nadu Agricultural University; 1980.

Sivrikaya H, Bacak L, Saraçbaşi A, Toroğlu İ, Eroğlu H. Trace elements in Pleurotus sajor-caju cultivated on chemithermomechanical pulp for bio-bleaching. Food Chemistry. 2002; 79: 173-176.

Syed Abrar Ahmed, .A.Kadam1, V.P. Mane, S.S. Patil and M.M.V. Baig. Biological Efficiency And Nutritional Contents Of Pleurotus florida (Mont.) Singer Cultivated On Different Agro-wastes. Nature and Science, 2009; 7(1), ISSN 1545-0740.

Szabová, E., Rohal'ová, L., Hedvigy, M., 2013. Semi-solid fermentation of Pleurotus ostreatus. Journal of Microbiology, Biotechnology and Food Sciences, 2, 1950-1958.

Tesfaw, A., Tadesse, A., Kiros, G., 2015. Optimization of oyster (Pleurotus ostreatus) mushroom cultivation using locally available substrates and materials in Debre Berhan, Ethiopia. Journal of Applied Biology \& Biotechnology 3, 15-20.

Wankhede, D.B., Tharanthan, R., N., 1976. Sesame (Sesamum indicum) carbohydrates. Journal of Agricultural and Food Chemistry. 24, 655 - 659.

\section{How to cite this article:}

Rafat Khalaphallah, Tharwat EL-Ameen, Reham A. Abd EL-Rahmen and Eman S. Farrag. 2020. Effect of Different Agro-wastes Substrates on the Growth and Productivity of the Oyster Mushroom in Upper Egypt. Int.J.Curr.Microbiol.App.Sci. 9(04): 24-32. doi: https://doi.org/10.20546/ijcmas.2020.904.005 